TEACHING : Jurnal Inovasi Keguruan dan IImu Pendidikan

Vol. 1. No. 4 Desember 2021 e-ISSN : 2775-7188 | p-ISSN : 2775-717X

\title{
TINGKAT KETERBACAAN BUKU SEKOLAH ELEKTRONIK (BSE) PELAJARAN BIOLOGI KELAS X SMA/MA
}

\author{
UMUL MURSYADAH
}

Universitas Indraprasta PGRI

e-mail : umul.bio@gmail.com

\begin{abstract}
ABSTRAK
Penelitian ini bertujuan untuk mengetahui keterbacaan Buku Sekolah Elektronik (BSE) pelajaran Biologi Kelas X. Penelitian ini dilakukan di MAN 13 Jakarta. Metode penelitian yang digunakan adalah metode penelitian deskriptif. Populasi dari penelitian ini adalah seluruh BSE Biologi kelas X SMA/MA serta seluruh siswa kelas X MA di Jakarta Selatan. Pengambilan sampel dilakukan dengan purposive sampling. Sampel buku hanya ditemukan satu BSE Biologi kelas X SMA/MA yang digunakan di MA Jakarta Selatan. Teks yang diteliti adalah teks yang telah dipelajari pada materi bab 1 sampai bab 5. Satu bab diwakili oleh satu teks, sehingga didapat lima teks yang diteliti. Sampel siswa diambil berdasarkan MA yang menggunakan BSE Biologi yaitu MAN 13 Jakarta. Pengukuran keterbacaan dilakukan menggunakan tes rumpang proposisi dan grafik fry. Hasil analisis menunjukkan bahwa keterbacaan BSE Biologi berdasarkan tes rumpang proposisi adalah seluruh teks termasuk kategori tinggi. Serta hasil keterbacaan berdasarkan grafik fry adalah satu teks termasuk cocok untuk kelas X SMA/MA, dua teks terlalu mudah dan dua teks terlalu sulit untuk kelas X SMA/MA. Penelitian ini menunjukkan kualitas buku teks dari segi keterbacaan, agar menjadi pertimbangan bagi guru dan siswa dalam memilih buku teks pelajaran yang berkualitas baik.
\end{abstract}

Kata Kunci : Keterbacaan, Buku Sekolah Elektronik (BSE), Tes Rumpang, Grafik Fry.

\section{ABSTRACT}

This research was aimed to determine the readability of Biology School Electronic Book (BSE) for $10^{\text {th }}$ grade. The research was conducted in MAN 13 Jakarta. The method of this research was descriptive. Population of this research were all biology BSE of $10^{\text {th }}$ SMA/MA and all student of $10^{\text {th }}$ MA in South Jakarta. Sampling was done by purposive sampling. Book sample found only one title of biology BSE class X SMA/MA which is used in MA of South Jakarta. The researched texts were texts which had been studied in $1^{\text {st }}$ to $5^{\text {th }}$ chapter. One chapter was represented by one text, so it was gotten five texts. Student samples were taken by MA which used biology BSE that was MAN 13 Jakarta. The measurements of readability used cloze test propositions and formula of fry graph. The results of analysis showed that readability biology BSE based cloze test proposition were all of the texts included to high level. And the results of readability based on the fry graph showed that one text was appropriate for class $10^{\text {th }} \mathrm{SMA} / \mathrm{MA}$, the two texts were too easy and two texts were too difficult for class $10^{\text {th }}$ SMA/MA. This research showed the quality of textbooks in terms of readability, in order to be consideration for teachers and students in selecting high quality textbooks.

Keywords: Readability, Electronic School Book (BSE), Cloze Test, Fry Graph.

\section{PENDAHULUAN}

Pendidikan adalah usaha sadar dan terencana yang dilakukan untuk mewujudkan manusia yang berkualitas baik sesuai dengan tujuan suatu Negara sebagaimana disebutkan dalam UndangUndang (UU) RI No. 20 Tahun 2003 tentang Sistem Pendidikan Nasional Bab 1 Pasal 1 yaitu:

"Pendidikan adalah usaha sadar dan terencana untuk mewujudkan suasana belajar dan proses pembelajaran agar peserta didik secara aktif mengembangkan potensi dirinya untuk memiliki kekuatan spiritual keagamaan, pengendalian diri, kepribadian, kecerdasan, akhlak mulia, serta keterampilan yang diperlukan dirinya, masyarakat, bangsa dan Negara". 
Berdasarkan UU RI di atas, pendidikan juga dimaknai sebagai proses pembelajaran. Proses pembelajaran merupakan interaksi yang terjadi antara pelajar, pengajar dan juga bahan ajar. Bahan ajar yang dimaksud adalah buku teks pelajaran. Seorang siswa perlu membaca buku teks untuk memahami materi pelajaran, sedangkan bagi guru buku teks pelajaran dapat mempermudah dalam menyampaikan materi pelajaran. Oleh karena itu keberadaan buku teks memiliki peran dan pengaruh terhadap proses pembelajaran. Sehingga pembelajaran dapat berjalan dengan baik dan sesuai tujuan yang diharapkan.

Buku teks memiliki peran yang besar di dunia pendidikan karena buku teks merupakan salah satu kebutuhan bagi siswa dan guru yang dapat mendukung dalam proses pembelajaran di sekolah. Demi terpenuhinya kebutuhan tersebut, pemerintah telah mengadakan buku teks pelajaran yang diunggah pada sebuah situs buku-buku teks pelajaran yang bernama situs program Buku Sekolah Elektronik (BSE). Buku Sekolah Elektronik (BSE) merupakan program buku murah yang disediakan oleh pemerintah untuk menjamin ketersedian buku teks pelajaran bagi guru, peserta didik dan seluruh masyarakat di tanah air Indonesia. Buku sekolah elektronik (BSE) ini disediakan dalam bentuk buku, CD/DVD yang dapat digandakan atau dapat diunduh di situs resmi http://www.bse.depdiknas.go.id. Setelah mendapatkan file-nya masyarakat bebas untuk menggandakannya dan diharapkan BSE ini dapat memenuhi kebutuhan masyarakat akan buku teks serta dapat dimanfaatkan untuk kepentingan pembelajaran.

Keterbacaan menurut Kamus Besar Bahasa Indonesia (KBBI) adalah perihal dapat dibacanya sebuah teks secara cepat serta mudah dipahami dan diingat. Tingkat keterbacaan suatu teks bisa didapatkan dengan dua cara yaitu dengan tes menggunakan formula keterbacaan dan tes kemampuan memahami bacaan oleh pembaca. Kedua tes ini berbeda, tes menggunakan formula hanya melibatkan teks tanpa melibatkan pembaca. Sedangkan tes pemahaman melibatkan pembaca. Pengukuran hanya dengan teks tanpa melibatkan pembaca dapat dilakukan dengan menggunakan formula Grafik Fry, Grafik Raygor dan Formula Flesch dan Tes SMOG. Pengukuran keterbacaan dengan melibatkan pembaca dapat menggunakan tes rumpang (Amas : 2007).

Berdasarkan Kamus Besar Bahasa Indonesia buku adalah kumpulan lembar kertas yang berjilid, ada yang berisi tulisan adapun yang kosong. Buku yang berisi tulisan adalah buku bacaan atau buku teks, buku yang demikian banyak digunakan dalam proses pembelajaran. Sedangkan buku yang kosong adalah buku yang biasa disebut dengan buku tulis (KBBI : 2005).

Ada juga ahli yang menjelaskan bahwa buku teks adalah sebuah buku pelajaran pada bidang studi tertentu yang merupakan buku standar, yang disusun oleh para pakar dalam bidang ilmu tertentu untuk maksud dan tujuan instruksional yang dilengkapi dengan sarana pengajaran yang serasi dan mudah dipahami oleh para penggunanya atau pembacanya di sekolah dan perguruan tinggi sehingga dapat menunjang program dan tujuan pembelajaran (Henry \& Djago Tarigan :2009)

Berdasarkan beberapa pengertian tentang buku teks di atas dapat disimpulkan bahwa buku teks adalah salah satu sumber belajar atau bahan ajar tertulis yang memiliki peran penting dalam proses pembelajaran di kelas sehingga membantu siswa untuk memahami pelajaran serta membantu guru untuk menyampaikan materi pelajaran demi tercapainya tujuan pendidikan.

Menurut Abdul (2011) buku teks juga merupakan salah satu sumber belajar. Dimana sumber belajar merupakan segala tempat atau lingkungan sekitar, benda, dan orang yang mengandung informasi dan dapat digunakan sebagai wahana bagi peserta didik untuk melakukan proses pembelajaran atau proses perubahan tingkah laku. Sumber belajar dapat berupa tempat atau lingkungan, benda, orang, buku dan peristiwa atau fakta yang sedang terjadi.

Selain itu buku teks juga termasuk bahan ajar karena buku teks merupakan salah satu bentuk bahan yang digunakan untuk membantu guru/instruktor dalam melaksanakan kegiatan belajar mengajar. Bahan ajar dapat berupa bahan tertulis maupun bahan tidak tertulis. Dan buku teks termasuk bahan ajar tertulis/bahan ajar cetak.

Mengingat pentingnya peran dari sebuah buku teks membuat pemilihan sebuah buku teks adalah keputusan yang sangat penting. Pentingnya sebuah buku teks mendorong 
banyaknya pengarang dan penerbit untuk memproduksi buku teks dalam jumlah yang banyak untuk berbagai tingkat siswa.

Banyak jenis buku teks yang dihasilkan oleh pengarang dan penerbit dibuat semenarik mungkin untuk meningkatkan jumlah penjualannya. Oleh karena itu, seorang guru harus mempunyai kemampuan untuk memutuskan mana buku teks yang cocok dengan karakter setiap individu siswanya. Setiap guru memerlukan informasi yang cukup tentang buku teks yang sesuai untuk bahan ajarnya.

Demi memenuhi kebutuhan dunia pendidikan terhadap buku teks yang layak digunakan untuk menunjang pembelajaran di sekolah. Maka pemerintah melakukaan pengadaan Buku Sekolah Elektronik (BSE).

BSE adalah salah satu program dari pemerintah dalam pengadaan buku teks pelajaran yang murah dan berkualitas. Pemerintah telah membeli hak cipta buku dari penulisnya tujuannya untuk memotong proses pembuatan buku pelajaran sehingga diharapkan harga buku bisa lebih murah karena buku-buku pelajaran yang telah dibeli hak ciptanya kemudian diubah menjadi bentuk digital atau ebook sehingga seluruh sekolah atau masyarakat di Indonesia dapat mengunduhnya secara gratis di portal JARDIKNAS misalnya yaitu http://www.bse.depdiknas.go.id atau www.sibi.or.id (Hotben : 2008).

Seperti yang disebutkan di aats salah satu aspek kelayakan sebuah buku teks adalah dari segi kelayakan bahasa yaitu termasuk keterbacaan di dalamnya. Keterbacaan sebuah buku dapat menentukan kualitas buku tersebut. Seperti yang dinyatakan oleh (Nurlaili : 2011) Sebuah wacana atau teks yang baik adalah yang terbaca dan terpahami oleh pembaca. Pembaca terbagi dalam berbagai level bergantung pada kemampuan membacanya. Pada hakikatnya membaca adalah proses berpikir. Karena seseorang yang membaca berarti harus bisa memaknai atau memahami setiap tulisan dalam wacana tersebut. Teks yang diharapkan dalam setiap tulisan adalah teks yang dapat dibaca dan dipahami oleh pembacanya. Keterbacaan pada teks memberikan hasil yang baik bagi pembacanya karena dengan adanya keterbacaan maka pembaca tidak hanya dapat membaca teks tetapi juga dapat memahami teks tersebut.

Dalam (Suherli : 2008) tingkat keterbacaan dapat dilakukan dengan dua cara yaitu dengan menilai respon pembaca dan mengukur dengan menggunakan formula keterbacaan. Formula keterbacaan adalah instrumen untuk memprediksi kesulitan memahami bacaan. Nilai keterbacaan dengan menggunakan formula didapat dari jumlah kata yang dianggap sulit, jumlah kata dalam kalimat, dan panjang kalimat dalam suatu teks. Ada beberapa formula keterbacaan yaitu tes SMOG, formula Flesch, Grafik Fry dan Grafik Raygor. Grafik Fry lebih banyak digunakan karena formulanya sederhana dan mudah digunakan. Dan untuk menilai respon pembaca atau keterpahaman membaca dapat menggunakan test cloze atau tes rumpang.

Dari penjelasan di atas maka dapat disimpulkan bahwa pendidikan adalah hal penting dalam kehidupan. Dalam mencapai pendidikan diperlukan suatu proses belajar. Belajar dapat dilakukan dimana saja termasuk di sekolah. Untuk menjalankan proses belajar di sekolah diperlukan suatu media yaitu salah satunya buku ajar atau buku teks. Buku teks yang digunakan untuk belajar di sekolah seharusnya buku teks yang memiliki kualitas baik terutama untuk keterbacaannya agar mudah dipahami siswa. Ada beberapa cara yang dapat dilakukan untuk mengukur tingkat keterbacaan buku teks.

Merujuk dari penelitian yang dilakukan oleh Amas Suryadi dengan judul Tingkat Keterbacaan Wacana Sains dengan Teknik Klos. Penelitian ini dilakukan untuk mengetahui tingkat keterbacaan buku kimia, biologi, fisika dan matematika yang digunakan oleh mahasiswa ITB dan hasilnya adalah buku kimia memiliki keterbacaan tingkat sedang, biologi termasuk keterbacaan tingkat sedang, keterbacaan buku fisika termasuk tingkat keterbacaan tinggi dan untuk buku matematika termasuk tingkat keterbacaan rendah. Dari hasil penelitian tersebut peneliti tertarik untuk melakukan penelitian pengukuran terhadap keterbacaan buku teks elektronik (BSE) biologi kelas X SMA dengan menggunkaan formula grafik Fry dan tes rumpang atau test cloze. 


\section{METODE PENELITIAN}

Penelitian ini dilaksanakan pada bulan April Tahun 2013, dengan tempat MAN 13 Jakarta. Dalam penelitian ini penulis menggunakan metode deskriptif. Metode yang dimaksudkan adalah untuk menggambarkan secara sistematik dan akurat mengenai fakta dan karakteristik suatu bidang kajian penelitian tertentu. Data yang dikumpulkan semata-mata deskriptif, sehingga tidak bermaksud mencari penjelasan, menguji hipotesis, membuat prediksi maupun mempelajari implikasi (Saifudin : 2010).

Populasi dari penelitian ini adalah seluruh Buku Sekolah Elektronik (BSE) Pelajaran Biologi kelas X SMA/MA yang digunakan di Madrasah Aliyah (MA) Jakarta Selatan. Sampel buku diambil berdasarkan hasil survey di MA Jaksel hanya ditemukan satu judul BSE pelajaran Biologi kelas X SMA/MA yaitu BSE Biologi kelas X SMA/MA yang ditulis oleh S W, S N R dan Z. Selanjutnya konsep yang akan diteliti adalah bab-bab yang telah dipelajari yaitu bab 1 sampai bab 5 pada Semester Satu (Ganjil). Pada masing-masing bab diwakili oleh 1 teks yang panjangnya sekitar 250 kata. Sehingga didapatkan 5 teks yang akan diuji keterbacaannya. Kelima teks tersebut berjudul : Biologi Merupakan Ilmu Pengetahuan Alam, Struktur dan fungsi virus, Ciri-Ciri Prokariotik, Filum Rhodophyta (Ganggang Merah) dab Klasifikasi Jamur. Sampel siswa diperoleh dari sekolah yang menggunakan BSE Biologi Karangan S W, dkk. yaitu MAN 13 Jakarta.

Penelitian ini menggunakan Instrumen tes rumpang dan grafik fry. Tes rumpang yang digunakan dalam penelitian ini yaitu tes rumpang berdasarkan proposisi. Instrumen tes rumpang proposisi merupakan tes rumpang yang dimaksudkan untuk melihat pemahaman siswa terhadap konsep yang terdapat pada suatu teks. Untuk validitas instrumen ditentukan dengan mengadakan konsultasi kepada dosen pembimbing dan dengan melakukan uji coba instrumen penelitian.

\section{HASIL DAN PEMBAHASAN}

Dalam penelitian ini, peneliti menganalisis tingkat keterbacaan Buku Sekolah Elektronik (BSE) Biologi yang digunakan di MA Se-Jakarta Selatan. Berdasarkan survey dari 6 MA yang terdapat di Jakarta selatan hanya 1 sekolah yang menggunakan BSE yaitu di MAN 13 Jakarta, BSE pelajaran Biologi kelas X yang digunakan berjudul Biologi SMA/MA Kelas X yang ditulis oleh S W, S N R dan Z dan diterbitkan oleh pusat perbukuan Departemen Pendidikan Nasional (Depdiknas) Jakarta pada tahun 2009.

BSE yang berjudul Biologi SMA/MA Kelas $X$ yang ditulis oleh S W, dkk. terdiri dari 288 halaman yang terbagi dalam 2 semester yaitu semester satu (ganjil) dan semester dua (genap). Semester satu terdiri atas lima bab, semester dua juga terdiri atas lima bab.

Teks yang digunakan untuk mengukur keterbacaan buku BSE ini diambil dari bab yang telah dipelajari. Pada saat penilitian bab-bab yang diambil hanya lima bab di semester ganjil. Setiap bab keterbacaannya diwakili oleh satu teks bacaan, sehingga didapatkan data keterbacaan lima teks yang selanjutnya diukur keterbacaannya dengan tes rumpang proposisi dan grafik fry.

\section{Hasil}

\section{Hasil Tes Rumpang}

Berikut ini akan dijelaskan hasil penelitian keterbacaan dari 5 teks berdasarkan tes rumpang disajikan dalam tabel berikut:

Tabel 1 Hasil Uji Keterbacaan Tes Rumpang Proposisi

\begin{tabular}{|c|c|c|}
\hline Teks & Hasil Tes Rumpang Proposisi (\%) & Keterangan \\
\hline 1 & $71,79 \%$ & Tinggi \\
\hline 2 & $87,14 \%$ & Tinggi \\
\hline 3 & $80,86 \%$ & Tinggi \\
\hline 4 & $86 \%$ & Tinggi \\
\hline 5 & $73,97 \%$ & Tinggi \\
\hline
\end{tabular}




\begin{tabular}{|c|c|c|}
\hline Jumlah & $399,76 \%$ & \\
\hline Rata-rata & $\mathbf{7 9 , 9 5 \%}$ & Tinggi \\
\hline
\end{tabular}

Pada tabel 1 dapat diketahui bahwa persentase hasil keterbacaan BSE pada masingmasing teks hasilnya berbeda-beda. Tapi seluruhnya masih termasuk kategori keterbacaan tinggi. Sehingga rata-ratanya secara umum seluruh teks pada buku tersebut termasuk kategori keterbacaan tinggi. Keterbacaan tinggi maksudnya teks-teks tersebut dapat dibaca dan dipahami sendiri oleh siswa tanpa memerlukan tambahan penjelasan dari guru.

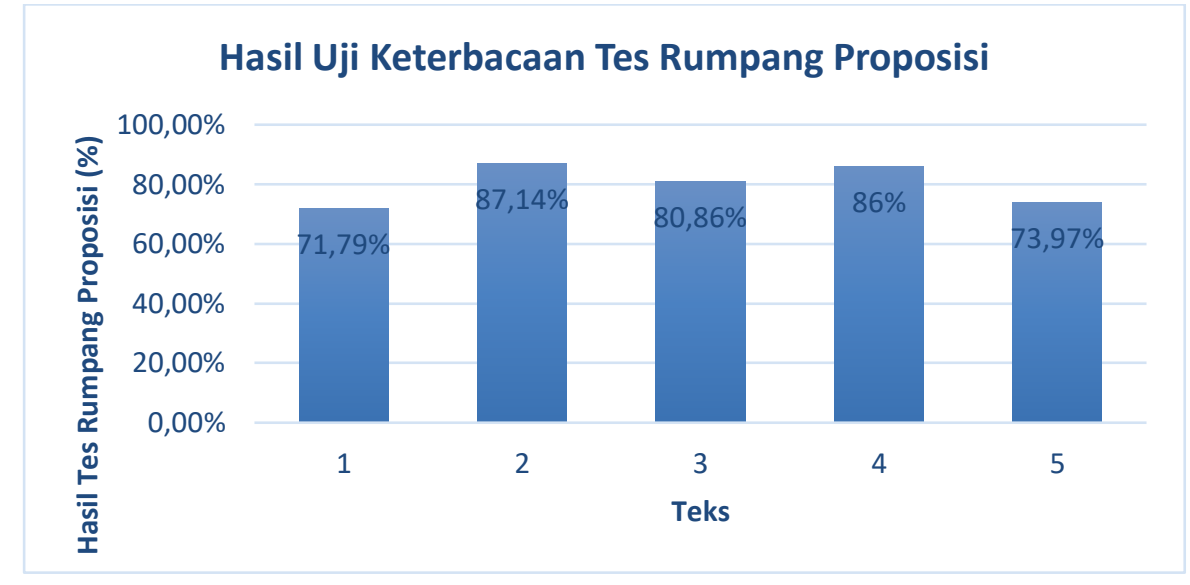

\section{Gambar 1. Grafik hasil keterbacaan tes rumpang proposisi}

Pada gambar 1 menunjukkan grafik hasil keterbacaan tes rumpang proposisi. Dimana hasil tersebut menunjukkan bahwa teks 1 hingga teks 5 memiliki nilai keterbacan di atas $70 \%$ yang menunjukkan bahwa semua teks memiliki keterbacaan tinggi sehingga wacana yang disajikan di dalam buku teks mudah dipahami siswa.

\section{Hasil Grafik Fry}

Berikut ini titik-titik hasil pertemuan perhitungan jumlah kalimat dan jumlah suku kata pada masing-masing teks dalam grafik fry. berikut :

Secara keseluruhan hasil keterbacaan dengan dengan grafik fry dapat dilihat pada tabel

Tabel 2 Hasil Keterbacaan dengan Grafik Fry

\begin{tabular}{|l|l|l|l|l|}
\hline Teks & $\begin{array}{l}\text { Jumlah } \\
\text { Kalimat }\end{array}$ & $\begin{array}{l}\text { Jumlah Suku } \\
\text { Kata }\end{array}$ & $\begin{array}{l}\text { Cocok untuk } \\
\text { kelas }\end{array}$ & Kategori \\
\hline 1 & 5,91 & 169,8 & $12,13,14$ & Sulit \\
\hline 2 & 7,5 & 142,8 & $6,7,8$ & Mudah \\
\hline 3 & 7,3 & 165,6 & $10,11,12$ & Cocok \\
\hline 4 & 8,83 & 151,8 & $6,7,8$ & Mudah \\
\hline 5 & 7,59 & 171,6 & $12,13,14$ & Sulit \\
\hline
\end{tabular}

Jadi dari lima teks yang diujikan hasilnya adalah teks ke-1 termasuk kategori terlalu sulit karena cocok untuk kelas 12, 13, 14. Teks ke-2 termasuk kategori terlalu mudah karena teks ke-2 cocok untuk kelas 6, 7, 8. Teks ke-3 cocok untuk kelas 10, 11, 12. Teks ke-4 terlalu mudah karena cocok untuk kelas 6, 7, 8 dan teks ke-5 termasuk terlalu sulit karena cocok untuk kelas $12,13,14$

\section{Pembahasan}

Buku teks yang baik harus memiliki kebenaran isi, penyajian yang sistematis, penggunaan bahasa dan keterbacaan yang baik serta grafika yang fungsional (Tim peneliti : 2006). Oleh karena itu keterbacaan merupakan salah satu faktor penting yang dapat menentukan kualitas suatu buku teks. 
Setelah melakukan penelitian keterbacaan, menilai hasil keterbacaan serta menghitung persentase-nya, selanjutnya penulis akan membahas hasil temuan pada penelitian.

\section{Hasil Keterbacaan Tes Rumpang Proposisi}

Hasil keterbacaan dengan tes rumpang berdasarkan proposisi secara umum pada semua teks termasuk kategori tinggi. Akan tetapi pada MP hasil keterbacaanya adalah tiga teks (teks 2, teks 3, teks 4) termasuk kategori keterbacaan tinggi dan dua teks (teks 1 dan teks 5) termasuk tingkat keterbacaan sedang. Sedangkan hasil keterbacaan dengan tes rumpang proposisi di MAN 13 menunjukkan bahwa semua teks memiliki tingkat keterbacaan yang tinggi. Perbedaan hasil keterbacaan ini terjadi karena siswa kelas X di MAN 13 Menggunakan BSE pelajaran Biologi Sri Widayati, sehingga mereka sudah terlebih dahulu membaca dan memahami konsep-konsep yang akan diujikan Sedangkan siswa kelas X di MP tidak menggunakan BSE pelajaran Biologi Sri Widayati. sehingga mereka belum pernah membaca dan kurang memahami konsep yang diujikan.

Karena tujuan dari tes rumpang dengan proposisi adalah untuk mengukur keterpahaman konsep. maka secara umum kelima teks yang diujikan dapat dipahami siswa. Paragraf pada teks ini menggunakan paragraf deduktif dimana setiap konsep dijelaskan secara umum terlebih dahulu kemudian diberikan penjelasannya.

Pada contoh paragraf-paragraf teks ke-1 sampai dengan teks ke-5, ide pokok paragrafnya terdapat pada kalimat pertama dan kalimat berikutnya berupa kalimat penjelas. Sesuai dengan teori yang dikemukakan oleh E. Zaenal arifin dan S. Arman Tasai bahwa syarat paragraf yang baik adalah memiliki kesatuan paragraf dan kepaduan paragraf. Kesatuan paragraf yaitu dalam satu paragraf hanya mengandung satu pokok pikiran, sedangkan kepaduan paragraf dapat dilihat dari penjelasan kalimat yang logis dan adanya pengait antar kalimat (Zaenal : 2009).

Menurut Henry (2009) Kohesi adalah bagaimana hubungan antar proposisi yang satu dengan yang lain sehingga membentuk suatu teks yang padu. Sedangkan koherensi adalah bagaimana caranya agar proposisi-proposisi yang tersirat atau terselubung dapat membantu menafsirkan atau menyimpulkan makna dan pesan dari suatu teks.

Pada kelima teks yang diujikan secara umum seluruh teks telah memiliki rasa kohesi dan koherensi yang baik, sehingga teks-teks tersebut dapat dipahami siswa. Oleh karena itu, secara umum semua teks yang diujikan ini termasuk kategori keterbacaan tinggi berdasarkan tes rumpang dengan proposisi karena teks ini dapat menyampaikan konsep materi biologi dengan baik sehingga dapat dipahami siswa.

\section{Hasil Keterbacaan dengan Grafik Fry}

Hasil keterbacaan teks berdasarkan grafik fry adalah satu teks yaitu teks ke-1 termasuk sesuai untuk digunakan oleh siswa kelas X SMA/MA, dan empat teks tidak sesuai untuk digunakan oleh siswa kelas X SMA/MA karena dua teks terlalu sulit dan dua teks lagi terlalu mudah untuk digunakan siswa kelas X SMA/MA.

Menurut (Nurlaili : 2011) penentuan tingkat keterbacaan teks menurut grafik fry adalah dengan pertimbangan panjang pendeknya kata yang ditandai oleh banyaknya jumlah suku kata pembentuk kalimat. Selain itu tingkat keterbacaan teks juga dipengaruhi oleh panjang wacana, panjang kalimat, dan pemilihan kata atau tingkat kesulitan kata.

Berdasarkan teori di atas maka dapat diketahui bahwa tinggi rendahnya keterbacaan suatu teks ditentukan oleh beberapa faktor yaitu, panjangnya teks atau wacana, panjangnya kalimat, dan pemilihan kata yang tidak sesuai. Faktor-faktor tersebut yang membuat hasil keterbacaan berdasarkan grafik fry pada penelitian ini berbeda-beda. Misalnya pada teks ke-1 dan teks ke-5 keterbacaaanya termasuk sulit karena wacananya terlalu panjang, kalimatnya panjang dan banyak kata-kata istilah yang maknanya kurang dipahami siswa. 


\section{KESIMPULAN}

Hasil penelitian keterbacaan BSE pelajaran Biologi dengan penulis S W, S N R dan Z, menunjukkan bahwa berdasarkan tes rumpang proposisi secara umum memiliki tingkat keterbacaan tinggi dengan rata-rata persentase sebesar 79,95\%. Persentase keterbacaan teks 1 sebesar $71,79 \%$, teks 2 mencapai $87,14 \%$, teks 3 sebesar $80,86 \%$, teks 4 sebesar $86 \%$ dan teks 5 sebesar $73,97 \%$.

Dilihat dari segi kesesuaian antara tingkat keterbacaan BSE ini dengan tingkat perkembangan siswa yang diukur dengan menggunakan formula grafik fry hasilnya menunjukkan bahwa keterbacaan BSE pelajaran Biologi dengan penulis S W, S N R dan Z, kurang sesuai dengan perkembangan siswa kelas 10. Hal ini ditunjukkan dengan hanya satu teks (teks ke-3) yang cocok untuk siswa kelas 10, dua teks (teks ke-1 dan teks ke-5) terlalu sulit dan cocok untuk kelas $12,13,14$. Serta dua teks yang lainnya (teks ke-2 dan teks ke-4) terlalu mudah untuk siswa kelas 10 dan cocok untuk siswa kelas 6, 7, 8. Ketidaksesuaian ini tentunya akan berdampak pada kualitas pemahaman siswa untuk memahami konsep-konsep biologi pada BSE ini.

\section{DAFTAR PUSTAKA}

Arifin, E. Zaenal dan S. Amran Tasai. Cermat Berbahasa Indonesia Untuk Perguruan Tinggi, Jakarta : PT. Nunggal Cipta, 2009.

Azwar, Saifuddin. Metode Penelitian. Yogyakarta : Pustaka Pelajar, 2010.

Harjasujana, A. Slamet, dkk. Evaluasi Keterbacaan Buku Teks Bahasa Sunda untuk Sekolah Dasar di Jawa Barat, Jakarta: Pusat Pembinaan dan Pengembangan Bahasa, 1999.

Kusmana, Suherli. Keterbacaan Buku Teks Pelajaran Berdasarkan Keterpahaman Bahasa Indonesi. Bahasa dan Sastra. 8, 2008.

Majid, Abdul. Perencanaan Pembelajaran Mengembangkan Standar Kompetensi Guru. Bandung: PT.Remaja Rosdakarya, 2011.

Nurlaili. Pengukuran Tingkat Keterbacaan Wacana dalam LKS Mata Pelajaran Bahasa Indonesia Kelas 4-6 SD dan Keterpahamiannya, Edisi Khusus No. 1, 2011.

Situmorang, Hotben. Isu Mutakhir Program e-book Depdiknas. Jurnal Pendidikan Penabur. 10, 2008.

Suryadi, Amas . Tingkat Keterbacaan Wacana Sains dengan Teknik Klos, Jurnal Sosioteknologi. 10, 2007.

Tarigan, Henry Guntur, dan Djago Tarigan. Telaah Buku Teks Bahasa Indonesia. Bandung: Angkasa, 2009.

Tarigan, Henry Guntur. Pengajaran Wacana. Bandung : Angkasa, 2009.

Tim Peneliti. Laporan Kajian Keterbacaan Buku Teks Sekolah Dasar. Jakarta: Pusat Perbukuan Departemen Pendidikan Nasional, 2006.

Undang-Undang (UU) RI No. 20 Tahun 2003 tentang Sistem Pendidikan Nasional Bab 1 Pasal 1. 